\title{
Pengembangan Aplikasi Planetarium Berbasis Virtual Reality
}

\author{
Ketut Gede Turangga ${ }^{1}$, I Gede Mahendra Darmawiguna ${ }^{2}$, Dewa Gede Hendra \\ Divayana $^{3}$ \\ 123 \\ Pendidikan Teknik Informatika, Universitas Pendidikan Ganesha \\ Singaraja, Bali \\ e-mail: ketutgedeturangga@gmail.com ${ }^{1}$, mahendra.darmawiguna@undiksha.ac.id ${ }^{2}$ \\ hendra.divayana@undiksha.ac.id ${ }^{3}$
}

\begin{abstract}
Abstrak
Penelitian ini bertujuan untuk mengembangkan sebuah aplikasi Planetarium Berbasis Virtual Reality. Adapun tujuan dari pengembangan aplikasi ini adalah untuk membantu masyarakat umum mempelajari ilmu astronomi dasar. Aplikasi ini memiliki 4 fitur utama yaitu ruang pameran untuk menampilkan obyek-obyek luar angkasa dan peralatan yang digunakan dalam astronomi, simulasi tata surya, rasi bintang, dan yang keempat adalah tur planet. Pengembangan aplikasi Planetarium berbasis Virtual Reality ini menggunakan model ADDIE. Ada lima tahap dalam model ADDIE yaitu Analisis (Analyze), Desain (Design), Pengembangan (Development), Implementasi (Implementation), dan Evaluasi (Evaluation). Berdasarkan hasil pengujian whitebox yang dilakukan didapatkan hasil bahwa seluruh algoritma yang digunakan dapat berjalan dengan baik dan pengujian blackbox untuk menguji kebenaran proses aplikasi mendapat hasil sebesar $100 \%$. Pada pengujian usability aplikasi, diketahui bahwa skala daya tarik aplikasi ini mencapai nilai 2,167 dan termasuk kedalam kategori sangat baik. Skala kejelasan 1,575 dengan predikat baik. Efisiensi mencapai nilai 2, ketepatan mencapai nilai 1,9 ; stimulasi mencapai nilai 2,25 ; dan skala yang terakhir yakni skala kebaruan yang mencapai nilai 1,925 atau dengan predikat sangat baik. Berdasarkan hasil tersebut aplikasi dapat dikatakan berjalan dengan baik sesuai dengan rancangan dan fungsionalnya.
\end{abstract}

Kata kunci: ADDIE, GoogleVR, Planetarium, Virtual Reality

\begin{abstract}
This study aimed to develop a Planetarium application based on Virtual Reality. this application is developed to help the public to learn basic astronomy. This application has 4 main features, namely; the exhibition hall for displaying objects of outer space and equipment used in astronomy, solar system simulations, constellations, and the fourth is a planet tour. Planetarium application based on Virtual Reality development is using ADDIE model. There are five stages in the ADDIE model: Analyze, Design, Development, Implementation, and Evaluation. According to the result of the whitebox testing, the whole algorithm that used are run well and the blackbox test is to test the correctness of the application process which gets $100 \%$. In the usability test of the application, it is known that the appeal scale of this application reached 2.167 and it included into a very well category. The 1.575 clarity scale with a good predicate. The efficiency of this application reaches value 2, the precision reaches value 1.9; the stimulation reached value 2.25, and the last scale is the scale of novelty that reaches the value of 1,925 or categorizes as a very good predicate. Based on these results the application can be said to run well in accordance with the design and functional.
\end{abstract}

Keywords : ADDIE, GoogleVR, Planetarium, Virtual Reality 


\section{PENDAHULUAN}

Dalam proses pengamatan benda-benda langit di alam semesta, manusia telah mengembangkan banyak peralatan yang digunakan untuk mengamati, mempelajari, memprediksi karakteristik maupun hal-hal lainnya yang ada di alam semesta ini. Sejak sekitar dua abad SM dicoba dibuat alat-alat yang menirukan gerak benda-benda itu, yang juga berfungsi sekaligus untuk menguji ketepatan teori yang ada saat itu. Kemudian sekitar abad 17 telah dikenal alat peraga yang disebut Planetarium, Stellarium, Tellurium, dan Lunarium. Pada akhir abad 17 telah dibuat dinding bola yang permukaan dalamnya digambari bintang-bintang atau diberi lubang kecil-kecil untuk dilalui cahaya matahari sebagai penggambaran letak bintang-bintang. Planetarium kuno pertama merupakan sebuah alat peraga atau model miniatur Tata Surya dengan menggunakan mesin mekanik, hasil karya tinggi dari tangan pembuat arloji. Alat peraga tersebut memang dibuat untuk mengenal waktu, dengan membuat peraga benda-benda langit yang bergerak yang dapat dijadikan acuan waktu astronomis. Cara-cara yang sederhana ini kemudian memberi dorongan munculnya pikiran-pikiran inovatif untuk menciptakan sistem proyeksi cahaya pada dinding bola yang terus digunakan sampai saat ini. Alat peraga yang berupa mesin mekanik yang dapat menggambarkan gerak planet-planet mengelilingi Matahari dengan teliti terakhir dibuat tahun 1924, tidak dapat bersaing dengan sistem proyeksi cahaya yang dilengkapi dengan mesin-mesin penggeraknya [1].

Dilansir dari situs resmi International Planetarium Society (IPS) yang merupakan asosiasi planetarium internasional, hingga 4 Maret 2008, jumlah planetarium di dunia terdapat lebih dari 3.300. Walaupun demikian, jumlah planetarium di dunia jauh lebih banyak bila planetarium mini milik sekolah ikut dihitung . Dibandingkan dengan jumlah planetarium yang ada di dunia, akan sangat berbanding terbalik dengan jumlah yang ada di Indonesia, jumlah planetarium yang terbuka untuk umum hanya 4 , yaitu Planetarium dan Observatorium TIM di Jakarta, Planetarium Jagad Raya Tenggarong di Kalimantan Timur, Museum Loka Jala Srana di Surabaya, dan Planetarium Taman Pintar di Yogyakarta.

Planetarium sebagai salah satu sarana belajar mengenai astronomi sekaligus sebagai sarana rekreasi bagi masyarakat memiliki peran yang besar dalam membantu mengenalkan ilmu astronomi dasar seperti benda-benda langit dan fenomena-fenomena yang terjadi di alam semesta. Namun, jika dilihat dari minimnya jumlah planetarium yang ada di Indonesia menyebabkan kesempatan untuk mengenali dan terlebih untuk mempelajari astronomi dasar di kalangan masyarakat masih rendah. Berdasarkan survey yang peneliti lakukan terhadap 100 responden di Kabupaten Buleleng menunjukkan bahwa 92\% responden belum mengetahui apa itu planetarium atau museum untuk melihat benda-benda langit atau peralatan dalam bidang astronomi seperti teleskop, baju astronaut dan sebagainya. Hal ini tentu disebabkan oleh sedikitnya jumlah planetarium yang ada di Indonesia. Kecilnya jumlah Planetarium yang ada di Indonesia ini tidak terlepas dari besarnya biaya yang dibutuhkan untuk membangun satu planetarium. Harga satu proyektor yang digunakan untuk menampilkan simulasi bintang ataupun tata surya di suatu planetarium buatan Carl Zeiss, berkisar antara 2,8 hingga 21 miliar rupiah bahkan bisa lebih dari itu tergantung pada ukuran kubah atau dome suatu planetarium.

Seiring dengan perkembangan ilmu pengetahuan dan teknologi yang demikian pesat, banyak teknologi baru yang dikembangkan untuk dapat memudahkan manusia dalam memenuhi kebutuhankebutuhan hidupnya. Salah satu tren pada tahun 2017 adalah teknologi virtual reality atau bisa disingkat VR. Virtual reality adalah teknologi yang membuat pengguna dapat berinteraksi dengan suatu lingkungan yang disimulasikan oleh komputer, suatu lingkungan sebenarnya yang ditiru atau benar-benar suatu lingkungan yang hanya ada dalam imajinasi [2].

Penggunaan virtual reality pada tahun 2014 2018 mengalami peningkatan secara konstan dimana pada tahun 2018 diperkirakan akan mencapai 28 juta. Begitu juga pada tipe perangkat virtual reality, sekitar $46 \%$ pengguna virtual reality menggunakan $P C, 28 \%$ menggunakan console, dan $26 \%$ menggunakan mobile pada tahun 2016 dari 10,8 juta pengguna [3].

Pemanfaatan teknologi virtual reality dalam mengembangkan suatu planetarium, tidak terlepas dari ketersediaan sumber daya ataupun perangkat-perangkat yang dibutuhkan seperti smartphone dan perangkat pendukungnya yang mudah untuk didapatkan dan memiliki harga 
yang terjangkau. Dari survei yang peneliti lakukan terhadap 100 masyarakat umum di kabupaten Buleleng menunjukkan 93\% dari responden memiliki perangkat smartphone berbasis Android. Tingkat ketertarikan masyarakat untuk mempelajari sistem tata surya atau fenomena-fenomena yang terjadi di dalamnya dengan bantuan Virtual Reality tergolong tinggi, yaitu sebesar $85 \%$.

Berdasarkan pemaparan tersebut peneliti berinisiatif untuk mengembangkan aplikasi Planetarium berbasis virtual reality yang diharapkan dapat memfasilitasi kebutuhan masyarakat khususnya masyarakat awam untuk mempelajari mengenai astronomi tingkat dasar. Lebih jauh masyarakat umum juga dapat menggunakan aplikasi Planetarium berbasis virtual reality ini sebagai media hiburan dan edukasi untuk menambah wawasan mengenai astronomi beserta fenomena-fenomena yang terjadi di alam semesta.

\section{LANDASAN TEORI}

\section{A. Planetarium}

Planetarium merupakan sarana wisata pendidikan yang menyajikan pertunjukan/menggambarkan peredaran dan letak planet-planet dalam tata surya, termasuk letak matahari yang menjadi pusat peredaran dengan menggunakan proyektor [4].

Planetarium adalah sebuah ruang dengan sebuah alat proyeksi yang secara akurat menggambarkan bintang-bintang dan planetplanet di setiap waktu baik masa lalu, masa sekarang maupun masa yang akan datang dari bagian bumi atau angkasa manapun. Planetarium merupakan tempat yang dirancang khusus, berkubah dan dilengkapi dengan peralatan optikal-mekanik untuk memperagakan suatu pertunjukkan tentang luar angkasa untuk tujuan pendidikan.

\section{B. Virtual Reality}

Virtual Reality (VR) atau realitas maya adalah teknologi yang membuat pengguna dapat berinteraksi dengan suatu lingkungan yang disimulasikan oleh komputer (computersimulated environment), suatu lingkungan sebenarnya yang ditiru atau benar-benar suatu lingkungan yang hanya ada dalam imajinasi [2]. Konsep VR mengacu pada sistem prinsipprinsip, metode dan teknik yang digunakan untuk merancang dan menciptakan produkproduk perangkat lunak untuk digunakan oleh bantuan dari beberapa sistem komputer multimedia dengan sistem perangkat khusus. Teknologi Virtual reality sekarang digunakan untuk terapi rehabilitasi fisik. Virtual reality memiliki kemampuan untuk menyimulasikan tugas di kehidupan nyata dan dengan beberapa manfaat nyata untuk rehabilitasi [5].

\section{Android}

Android is a software stack for mobile devices that includes an operating system, middleware and key applications. Most of you may already be aware of Android, its capabilities and other aspects. [6] Android 4.1 atau Jelly Bean akan digunakan sebagai standar minimal agar aplikasi dapat dijalankan.

\section{Unity3D}

Game engine Unity3D merupakan sebuah software (perangkat lunak) yang dirancang untuk dapat menciptakan atau mengembangkan video game. Fungsi utama yang disediakan oleh game engine biasanya mencakup renderer engine (mesin render) yang berguna untuk merender 2D atau 3D grafis, physics engine untuk membuat obyek 3D berlaku layaknya sebagai benda nyata (terpengaruh gravitasi, bertabrakan), sound (suara), script, animasi, kecerdasan buatan (Al), jaringan, streaming, manajemen memory, threading, dan grafik animasi. Ada banyak game engine yang dirancang untuk membuat game untuk berbagai platform seperti konsol video game dan sistem desktop seperti Microsoft Windows, Linux, dan Mac OS [7].

Dalam penelitian ini, perangkat lunak Unity3D akan dijadikan perangkat lunak utama untuk mengembangkan aplikasi Planetarium berbasis virtual reality. Hal ini tidak lepas dari pemaparan di atas mengenai berbagai fitur dan kelebihan yang dimiliki oleh perangkat lunak Unity3D ini. Salah satunya adalah sifatnya yang gratis (freeware) dan dapat menghasilkan perangkat lunak permainan untuk berbagai platform.

\section{E. GoogleVR SDK}

Google VR SDK for Unity adalah framework yang disediakan oleh google untuk membantu para pengembang untuk membuat sebuah aplikasi berbasis Virtual Reality (VR) yang 
secara langsung terintegrasi dengan Unity. Unity native integration dengan Google VR memudahkan untuk membangun aplikasi android untuk Daydream dan Cardboard [8].

\section{F. Blender}

Blender adalah salah satu software open source yang digunakan untuk membuat konten multimedia khususnya 3D, ada beberapa kelebihan yang dimiliki Blender dibandingkan software sejenis. Berikut beberapa kelebihannya: Open Source, Blender merupakan salah satu software open source, di mana kita bisa bebas memodifikasi source code-nya untuk keperluan pribadi maupun komersial, asal tidak melanggar GNU General Public License yang digunakan Blender. Multi Platform, karena sifatnya yang open source, Blender tersedia untuk berbagai macam operasi sistem seperti Linux, Mac dan Windows. Sehingga file yang dibuat menggunakan Blender versi Linux tak akan berubah ketika dibuka di Blender versi Mac maupun Windows [9].

Dalam penelitian ini, untuk pembuatan obyek dan animasi benda-benda langit pada aplikasi Planetarium berbasis virtual reality menggunakan perangkat lunak Blender. Blender digunakan karena memiliki fitur $3 D$ modeling, rigging, dan animasi. Selain itu Blender mudah digunakan, ukuran instalasi yang relatif kecil dan dapat diimplementasikan di semua platform.

\section{G. GIMP}

Gimp atau GNU Image Manipulation Program adalah perangkat lunak manipulasi gambar multi-platform, Gimp sangat cocok untuk mengerjakan berbagai macam manipulasi gambar, seperti memperbaiki kualitas photo, mengubah komposisi gambar dan merekonstruksi gambar juga untuk keperluan desain grafis baik untuk level amatir maupun profesional. Gimp memiliki berbagai kegunaan, mulai dari membuat berbagai jenis gambar sederhana, edit foto secara profesional, mengonversikan gambar baik dalam skala kecil maupun besar, dan sebagainya.

\section{H. ADDIE}

Model pengembangan ADDIE merupakan model desain pembelajaran yang berlandasan pada pendekatan sistem yang efektif dan efisien serta prosesnya yang bersifat interaktif yakni hasil evaluasi setiap fase dapat membawa pengembangan pembelajaran ke fase selanjutnya. Hasil akhir dari suatu fase merupakan produk awal bagi fase berikutnya.

Model ini terdiri atas 5 fase atau tahap utama yaitu 1) Analyze (Analisis), 2) Design (Desain), 3) Develop (Pengembangan), 4) Implement (Implementasi), 5) Evaluate (Evaluasi) [10].

\section{METODOLOGI}

Penelitian mengenai pengembangan aplikasi Planetarium berbasis virtual reality ini menggunakan metode penelitian pengembangan atau Research and Development (R\&D). Metode penelitian dan pengembangan atau Research and Development (R\&D) merupakan metode yang digunakan untuk menghasilkan produk tertentu, dan menguji keefektifan produk tersebut [11]. Untuk menghasilkan suatu produk digunakan penelitian yang bersifat analisis kebutuhan dan untuk menguji keefektifan produk tersebut supaya dapat berfungsi di masyarakat luas, maka diperlukan penelitian untuk menguji keefektifan produk tersebut. Jenis penelitian ini dipilih karena prosedur yang ada di dalamnya sangat tepat untuk melakukan pengembangan sebuah bahan ajar yang mempunyai tujuan untuk mengembangkan dan memvalidasi produk.

Pengembangan Aplikasi Planetarium Berbasis Virtual Reality menggunakan model ADDIE atau Analysis, Design, Development, Implementation dan Evaluation [12]. Model ini merupakan model yang berlandasan pada pendekatan sistem yang efektif dan efisien serta prosesnya yang bersifat interaktif yakni hasil dari setiap fase dapat digunakan di fase berikutnya. Sederhananya hasil akhir dari suatu fase merupakan produk awal bagi fase berikutnya. Salah satu fungsi ADDIE yaitu sebagai pedoman dalam membangun perangkat dan infrastruktur program yang efektif dan dinamis. Model ADDIE ini sangatlah mudah untuk dijadikan landasan atau pedoman dalam pengembangan sebuah produk. Hal ini 
disebabkan karena model ADDIE menggunakan pendekatan produk dengan langkah-langkah sistematis dan interaktif. Model ADDIE terdiri dari 5 fase, yaitu Analysis (Analisis), Design (Desain), Development (Pengembangan), Implementation (Implementasi) dan Evaluate (Evaluasi). Model penelitian ADDIE pada pengembangan Aplikasi Planetarium berbasis virtual reality ini digambarkan pada Gambar 1.

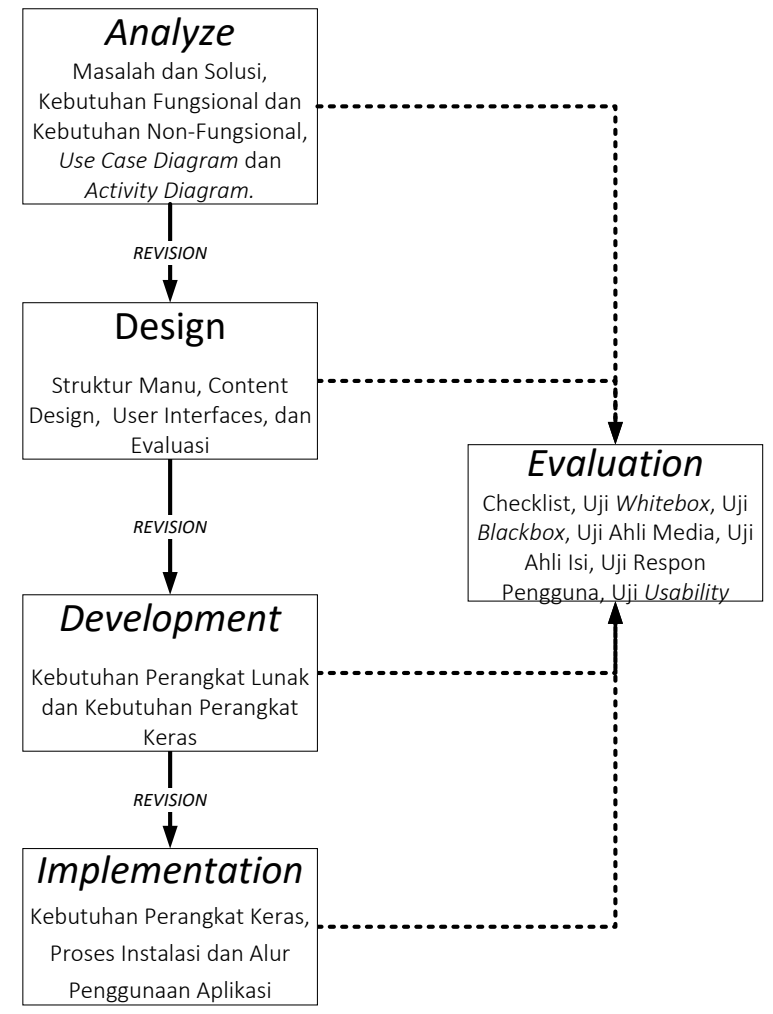

Gambar 1. Model Penelitian ADDIE pada Pengembangan Aplikasi Planetarium Berbasis Virtual Reality

Fase analisis merupakan fase awal dari pengembangan model ADDIE dimana pada fase ini akan dilakukan pengumpulan informasi dan kebutuhan secara lengkap dan kemudian dianalisis dan didefinisikan kebutuhankebutuhan yang harus dipenuhi oleh aplikasi yang akan dibangun. Dalam pengembangan Aplikasi Planetarium berbasis virtual reality, yang pertama dilakukan adalah melakukan analisis kebutuhan dan dilanjutkan dengan membuat Use Case dan Activity Diagram. Sebelum dilanjutkan ke fase berikutnya, peneliti akan melakukan evaluasi terhadap produk yang telah dihasilkan pada tahap analisis ini menggunakan daftar atau checklist yang nantinya divalidasi oleh dosen pembimbing.

Fase yang kedua adalah perancangan atau persiapan sebelum mengembangkan aplikasi. Adapun perancangan yang dilakukan dalam pengembangan Aplikasi Planetarium berbasis virtual reality yaitu:

1. Melakukan perancangan struktur menu aplikasi

2. Perancangan isi atau konten dari fitur-fitur utama aplikasi

3. Perancangan antarmuka aplikasi

4. Perancangan evaluasi untuk setiap tahapan ADDIE

Sebelum dilanjutkan ke fase pengembangan, produk dari fase kedua ini akan dievaluasi setelah dilakukan pengujian ataupun validasi yang melibatkan ahli isi dan ahli media. Pada fase ketiga dari model ADDIE adalah fase pengembangan. Pada fase ini akan dilakukan proses pengembangan aplikasi. Pada tahap pengembangan didahului dengan membuat dan menyesuaikan assets (musik, narasi, obyek 3D dan desain menu) yang digunakan dalam aplikasi Planetarium berbasis virtual reality. Setelah assets sudah dibuat maka selanjutnya mengembangkan game dengan menggunakan game engine yaitu dengan menggunakan Unity 3D dan mengimplantasikan rancangan antarmuka, struktur menu dan isi atau konten yang ada pada fitur-fitur pada aplikasi planetarium berbasis virtual reality. Produk yang telah dihasilkan pada fase pengembangan akan divalidasi ataupun diuji terlebih dahulu oleh peneliti menggunakan metode pengujian blackbox dan whitebox.

Setelah aplikasi selesai dibangun dan direvisi, maka selanjutnya yaitu fase implementasi. Tahap implementasi adalah tahap saat aplikasi telah siap untuk diperkenalkan, dipasarkan dan dilakukan pengujian kelayakan. Pada fase implementasi akan dilakukan uji coba aplikasi dan pengujian terhadap aplikasi untuk mengetahui apakah aplikasi yang dibangun sudah berjalan dengan baik atau tidak. Evaluasi pada fase ini akan melibatkan kembali ahli isi dan ahli media sehingga aplikasi yang telah dikembangkan dan diimplementasikan sudah sesuai dengan desain yang dibuat. Selanjutnya akan dilakukan perbaikan sesuai hasil pengujian untuk mengurangi kesalahan-kesalahan yang terjadi 
sebelum diimplementasikan ke masyarakat luas.

Setelah proses implementasi selesai, dilanjutkan dengan proses evaluasi akhir untuk mengukur keberhasilan dari hasil uji coba pada tahap implementasi. Pada tahap evaluasi ini dilakukan pengujian untuk mengetahui respon masyarakat sasaran terhadap aplikasi yang peneliti kembangkan. Pengujian yang dilakukan adalah uji usability dan uji respon pengguna. Metode pengujian yang akan digunakan untuk mengetahui respon pengguna adalah metode angket. Sedangkan metode yang digunakan untuk mengetahui usability dari aplikasi adalah metode angket UEQ.

\section{HASIL DAN PEMBAHASAN}

\section{Hasil Tahap Analysis}

Pada tahap ini, peneliti mengidentifikasi masalah-masalah yang ditemukan sehingga dapat dijadikan acuan untuk mengembangkan aplikasi Planetarium berbasis virtual reality. Analisis masalah dan usulan solusi yang didapat digali dengan melakukan penyebaran angket/kuesioner (daftar pertanyaan kuesioner dapat dilihat pada Lampiran 1 dan hasil penyebaran kuesioner dapat dilihat pada Lampiran 2) dan metode observasi. Berdasarkan penyebaran angket yang peneliti lakukan terkait pengetahuan masyarakat mengenai astronomi dan fasilitas yang digunakan untuk mempelajari astronomi, terdapat beberapa masalah yang menjadi temuan peneliti adalah sebagai berikut.

a. Tingkat pemahaman masyarakat mengenai benda-benda langit dan fenomena-fenomena yang terjadi di alam semesta khususnya di sistem tata surya hanya $60 \%$ sehingga dapat dikatakan masih tergolong rendah.

b. Jumlah masyarakat yang belum mengetahui apa itu Planetarium sebanyak $92 \%$.

C. Planetarium yang digunakan sebagai fasilitas untuk mempelajari ilmu astronomi bagi masyarakat umum, jumlahnya di Indonesia masih sedikit.

d. Sebanyak $60 \%$ masyarakat masih mempelajari astronomi menggunakan buku yang memiliki kelemahan pada representasi informasi yang berbasis dimensi dua atau $2 D$.

Berdasarkan analisis masalah di atas maka solusi yang dapat diusulkan adalah aplikasi Planetarium berbasis virtual reality yang akan dikembangkan ini akan dapat menangani permasalahan yang menjadi temuan peneliti tersebut adalah sebagai berikut.

a. Aplikasi Planetarium berbasis virtual reality menampilkan benda-benda langit, alat-alat dalam bidang ilmu astronomi, dan fenomenafenomena yang terjadi dalam sistem tata surya dalam bentuk 3 dimensi sehingga pengguna dapat melihat obyek-obyek tersebut secara nyata.

b. Aplikasi Planetarium berbasis virtual reality dilengkapi dengan text, suara, dan animasi dari benda-benda langit, alat-alat dalam bidang ilmu astronomi, dan fenomenafenomena yang terjadi dalam sistem tata surya.

Berdasarkan analisis masalah dan solusi, pada pengembangan aplikasi Planetarium berbasis virtual reality didapatkan beberapa kebutuhan fungsional sebagai berikut, yaitu:

a. (SKPL-F-01) Menampilkan ruang pameran yang memuat benda-benda langit dan alatalat yang digunakan dalam bidang astronomi berbasis virtual reality beserta teks informasi dari obyek yang dipilih oleh pengguna, memainkan animasi dan suara berupa dubbing deskripsi dari obyek tersebut.

b. (SKPL-F-02) Menampilkan simulasi tata surya yang memuat simulasi pergerakan planet-planet dalam sistem tata surya pada garis orbitnya (rotasi dan revolusi) serta menampilkan kepada pengguna nama dari setiap planet yang ada.

c. (SKPL-F-03) Menampilkan kepada pengguna informasi mengenai kondisi umum, atmosfer, satelit, dan fakta unik beserta dubbing deskripsi dari 8 planet yang ada di dalam sistem tata surya sesuai dengan planet yang dipilih oleh pengguna.

d. (SKPL-F-04) Menampilkan kepada pengguna rasi-rasi bintang yang dipilih beserta deskripsinya.

e. (SKPL-F-05) Menampilkan kepada pengguna menu pengaturan bahasa dan volume suara.

f. (SKPL-F-06) Menampilkan kepada pengguna informasi mengenai pengembangan aplikasi planetarium berbasis virtual reality.

g. (SKPL-F-07) Menampilkan kepada pengguna informasi mengenai kredit untuk aset yang digunakan pada aplikasi planetarium berbasis virtual reality. 
Berdasarkan analisis pada pengembangan aplikasi Planetarium berbasis virtual reality, terdapat beberapa kebutuhan non fungsional sebagai berikut:

a. Compatibility (SKPL-NF-01) berjalan pada perangkat dengan sistem operasi Android minimal versi 4.1 (Jelly Bean) dan memiliki sensor gyroscope.

b. Usability (SKPL-NF-02) memiliki tampilan yang user friendly, tujuannya agar pengguna merasa tertarik dan lebih mudah menggunakan aplikasi. Untuk memenuhi kebutuhan non fungsional ini, peneliti melakukan survey sehingga didapatkan suatu kesimpulan untuk membuat rancangan antarmuka yang ramah pengguna.

C. Efficiency (SKPL-NF-03) dapat dijalankan pada perangkat smartphone Android kelas mid-end dan kapasitas penyimpanan yang dibutuhkan oleh aplikasi maksimal $500 \mathrm{MB}$. Berdasarkan hasil survey yang peneliti lakukan didapatkan fakta bahwa masyarakat menggunakan perangkat Android dengan kapasitas penyimpanan diatas $1 \mathrm{~GB}$ sebanyak $80 \%$. Sehingga memungkinkan pengembang untuk mengimplementasikan aplikasi planetarium berbasis virtual reality ini ke perangkat masyarakat.

d. Reliability (SKPL-NF-04) dapat dijalankan tanpa menyebabkan crash terhadap aplikasi berjalan lainnya atau sistem operasi pada vendor smartphone berbeda.

e. Portability (SKPL-NF-05) dapat dijalankan pada perangkat smartphone Android secara offline.

Pemodelan fungsional perangkat lunak pada penelitian ini peneliti menggunakan UML (Unified Modeling Language). Unified Modelling Language (UML) adalah sebuah "bahasa" yang telah menjadi standar dalam industri untuk menentukan, visualisasi, merancang dan mendokumentasikan artifact dari sistem software, untuk memodelkan bisnis dan sistem non software lainnya. UML merupakan suatu kumpulan teknik terbaik yang telah terbukti sukses dalam permodelan sistem yang besar dan kompleks [13].

Use case diagram menggambarkan fungsionalitas yang diharapkan dari sebuah sistem. Seorang/sebuah aktor adalah sebuah entitas manusia atau mesin yang berinteraksi dengan sistem untuk melakukan pekerjaanpekerjaan tertentu.

Use case diagram pada Gambar 2 menunjukkan user atau pengguna dapat:
Menampilkan Ruang Pameran (SKPL-F-01), Menampilkan Simulasi Tata Surya (SKPL-F-02), Menampilkan Tur Planet (SKPL-F-03), Menampilkan Rasi Bintang (SKPL-F-04), Melakukan Pengaturan (SKPL-F-05), Menampilkan Tentang Pengembang (SKPL-F06) dan Menampilkan Credit Aplikasi (SKPL-F07).

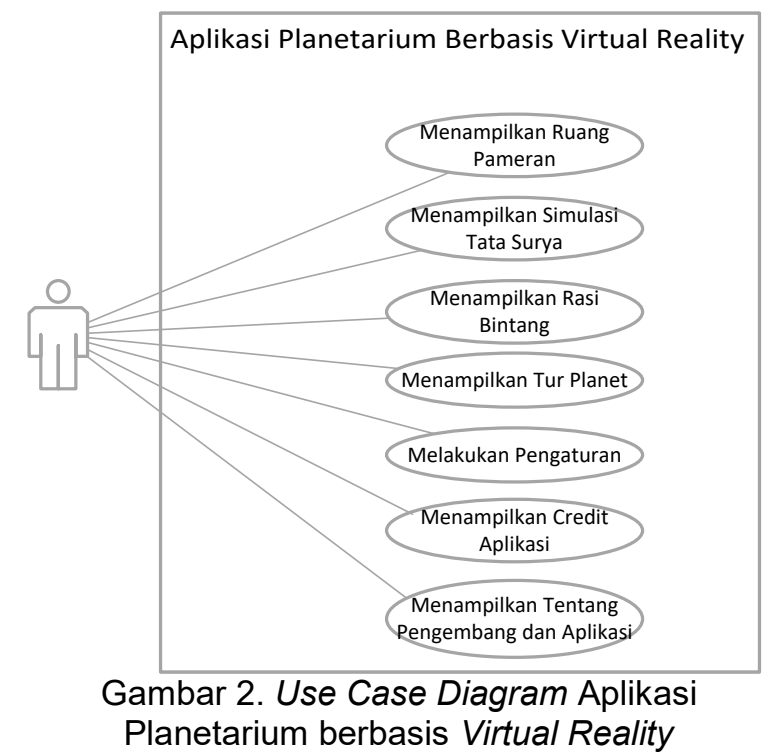

\section{Hasil Tahap Design}

Pada tahap desain, peneliti akan membahas mengenai desain konten-konten untuk setiap fitur utama dan antarmuka dari aplikasi Planetarium berbasis virtual reality yang peneliti kembangkan. Terdapat empat fitur utama pada aplikasi yang akan dikembangkan yaitu ruang pameran (SKPL-F-01), simulasi tata surya (SKPL-F-02), tur planet (SKPL-F-03), dan rasi bintang (SKPL-F-04).

Konten aplikasi pada ruang pameran yaitu Astronaut, Teleskop, Teleskop Hubble, Misi Kepler, Wahana Galileo, Asteroid Geographos, Asteroid Mithra, Asteroid Toutatis, Vesta, Pesawat Voyager 1, Pesawat Cassini-Huygens, Pesawat Ulang Alik, Pesawat Antariksa MAVEN, ISS, Robot Penjelajah Curiosity. Yang kedua yaitu konten simulasi tata surya antara lain Matahari, Merkurius, Venus, Bumi, Mars, Yupiter, Saturnus, Uranus, dan Neptunus. Yang ketiga konten pada rasi bintang yaitu rasi Andromeda, Antlia, Apus, Aquarius, Aquila, Ara, Aries, Auriga, Bootes, Caelum, Camelopardalis, Cancer, Canes Venatici, Canis Major, Canis Minor, Capricornus, Carina, Cassiopeia, Centaurus, Cepheus, Cetus, Chamaeleon, Circinus, Columba, Coma Berenices, Corona Australis, Corona Borealis, Corvus, Crater, Crux, Cygnus, Delphinus, Dorado, Draco, 
Equuleus, Eridanus, Fornax, Gemini, Grus, Hercules, Horologium, Hydra, Hydrus, Indus, Lacerta, Leo, Leo Minor, Lepus, Libra, Lupus, Lynx, Lyra, Mensa, Microscopium, Monoceros, Musca, Norma, Octans, Ophiuchus, Orion, Pavo, Pegasus, Perseus, Phoenix, Pictor, Pisces, Piscis Austrinus, Puppis, Pyxis, Reticulum, Sagitta, Sagittarius, Scorpius, Sculptor, Scutum, Serpens Caput, Serpens Cauda, Sextans, Taurus, Telescopium, Triangulum, Triangulum, Australe, Tucana, Ursa Major, Ursa Minor, Vela, Virgo, Volans, Vulpecula [14]. Yang keempat adalah konten tur planet. Pengguna dapat melihat beberapa planet antara lain Merkurius, Venus, Bumi, Mars, Yupiter, Saturnus, Uranus, dan Neptunus.

Pada tahap selanjutnya dilakukan perancangan antarmuka aplikasi, yaitu membuat rancangan tampilan dari aplikasi Planetarium berbasis Virtual Reality yang berfungsi untuk menghubungkan pengguna dengan perangkat lunak aplikasi agar dapat berinteraksi. Aplikasi ini memiliki rancangan antarmuka yang sederhana, mudah digunakan, dan dipahami oleh pengguna.

Pada tahap evaluasi akan dilakukan pengujian terhadap setiap tahap pada metode ADDIE. Pengujian ini bertujuan untuk mengetahui kekurangan dan kelemahan maupun kesalahan (error) dari aplikasi yang dikembangkan. Sehingga aplikasi masih bisa diperbaiki untuk mengurangi kesalahankesalahan yang terjadi sebelum diimplementasikan ke masyarakat luas. Pada tahap evaluasi akan dilakukan 6 jenis pengujian yaitu Uji Whitebox, Uji Blackbox, Uji Ahli Media, Uji Ahli Isi, Uji respon pengguna dan Uji usability.

\section{Hasil Tahap Development}

Pada pengembangan aplikasi Planetarium Berbasis Virtual Reality, arsitektur perangkat lunak yang telah dirancang sedemikian rupa selanjutnya dikembangkan sehingga dapat memenuhi seluruh kebutuhan fungsional yang sudah ditentukan. Pengembangan arsitektur perangkat lunak yaitu GvrViewer.cs, GvrReticle.cs, Language.cs, LocalizationText.cs, RemoteControl.cs, UIManager.cs, ControlFlyer.cs, FollowTarget.cs, Orbit.cs, Deskripsiplanet.cs, ToggleInfo.cs, InteractableObject.cs,

RigidbodyFirstPersonController.cs,

RasiBintangInfo.cs, PlaySound_Awal.cs, ToggleGambar.cs, DescManager.cs. Pada Unity pembuatan class - class dan fungsi menggunakan bahasa pemrograman $\mathrm{C \#}$ atau $\mathrm{C}$ Sharp dengan extensi file ".cs".

Berikut adalah hasil pengembangan dari perancangan antarmuka aplikasi Planetarium berbasis Virtual Reality berdasarkan perancangan antarmuka yang telah dilakukan pada tahap desain.

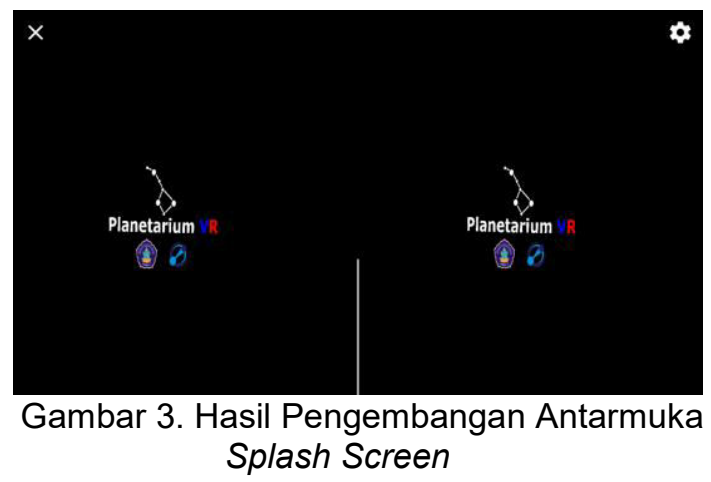

Antarmuka Splash Screen akan muncul pertama kali saat aplikasi dibuka. Setelah tampil splash screen, maka aplikasi akan menampilkan menu utama.

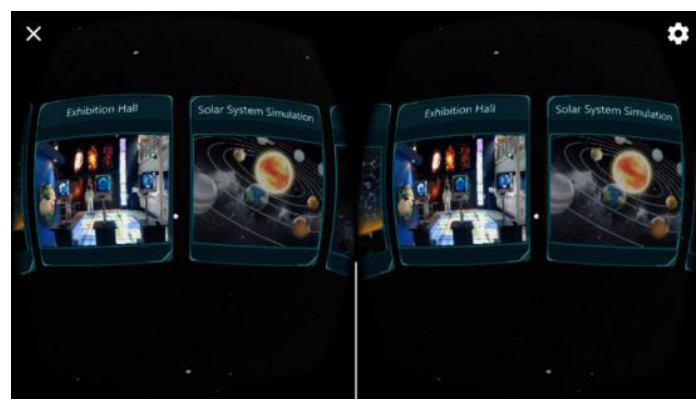

Gambar 4. Hasil Pengembangan Antarmuka Menu Utama

Antarmuka Menu Utama akan ditampilkan kepada pengguna yang memuat beberapa menu yaitu tentang, pengaturan, rasi bintang, ruang pameran, simulasi tata surya, tur planet, credit dan keluar aplikasi. Terdapat titik di tengah layar yang berfungi sebagai pointer atau penunjuk. Penunjuk ini akan berfungsi untuk menentukan menu mana yang akan dipilih oleh pengguna.

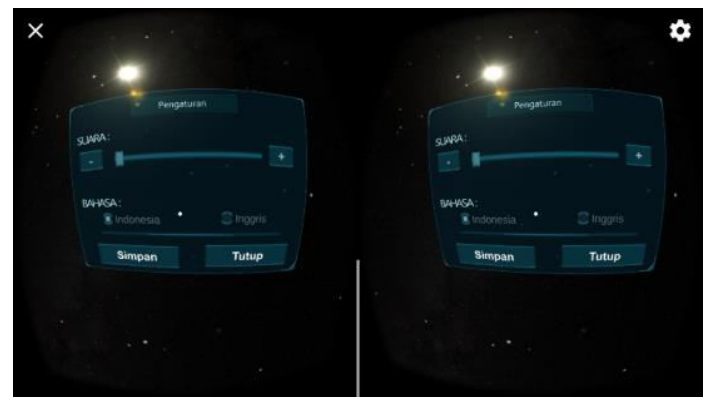


Gambar 5. Hasil Pengembangan Antarmuka Pengaturan

Antarmuka Pengaturan akan ditampilkan apabila pengguna memilih Menu Pengaturan pada menu utama. Tampilan pengaturan ini nantinya ditampilkan secara virtual reality di mana layar akan terbagi menjadi dua sisi yaitu sisi kanan dan sisi kiri. Di bagian tengah layar akan terdapat penunjuk atau pointer yang berfungsi sebagai penunjuk bagian mana yang akan dipilih oleh pengguna. Untuk mengatur keras atau kecilnya volume suara dari aplikasi, pengguna dapat menunjuk tanda + atau -. Untuk mengatur bahasa, pengguna dapat menunjuk salah satu radio button dari bahasa yang ada dengan menggunakan pointer yang ada di layar aplikasi. Tombol Simpan digunakan untuk menyimpan pengaturan yang telah dilakukan pengguna. Tombol tutup akan menutup menu antarmuka pengaturan dan menampilkan antarmuka Menu Utama.

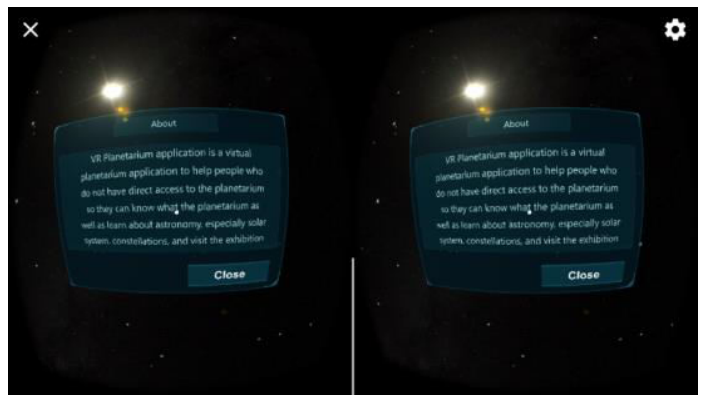

Gambar 6. Hasil Pengembangan Antarmuka Pengaturan

Antarmuka Pengaturan ini akan ditampilkan apabila pengguna memilih Menu Tentang pada menu utama. Tampilan tentang pengembang ini nantinya ditampilkan secara virtual reality di mana layar akan terbagi menjadi dua sisi yaitu sisi kanan dan sisi kiri. Di bagian tengah layar akan terdapat penunjuk atau pointer yang berfungsi sebagai penunjuk bagian mana yang akan dipilih oleh pengguna. Tombol tutup akan menutup menu antarmuka tentang pengembang dan menampilkan antarmuka Menu Utama.

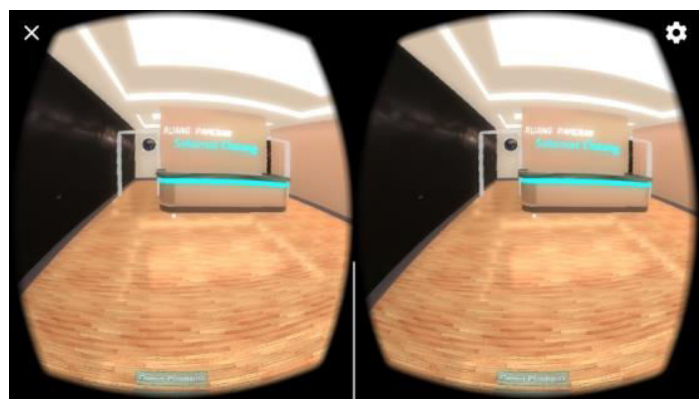

Gambar 7. Hasil Pengembangan Antarmuka Ruang Pameran

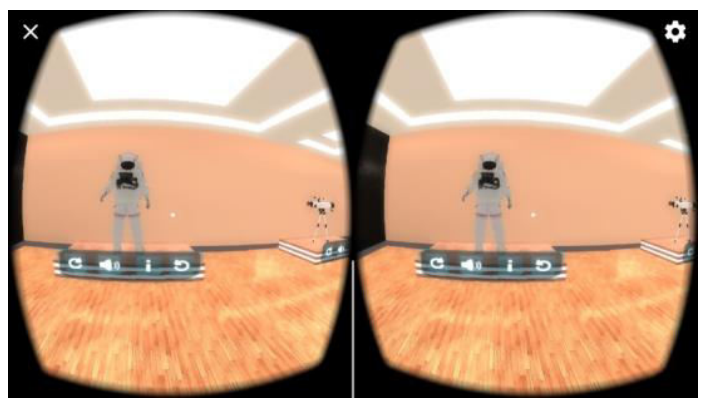

Gambar 8. Hasil Pengembangan Antarmuka Detail Obyek Ruang Pameran

Antarmuka pada Gambar 7 dan 8 akan ditampilkan apabila pengguna memilih Menu Ruang Pameran pada menu utama. Pengguna dapat mengeksplorasi ruang pameran yang tersedia dan melihat obyek-obyek yang ada. Setiap obyek memiliki deskripsi dan narasi suara untuk memperjelas informasi dari obyek tersebut. Pengguna dapat memilih tombol narasi untuk mendengarkan narasi dari obyek yang dipilih. Pengguna juga dapat memutar obyek dengan menekan tombol rotasi yang telah disediakan. Tombol "menu utama" berfungsi untuk kembali ke menu utama dan tombol reset posisi untuk mengembalikan posisi pengguna ke lokasi awal dimulainya fitur ruang pameran ini.

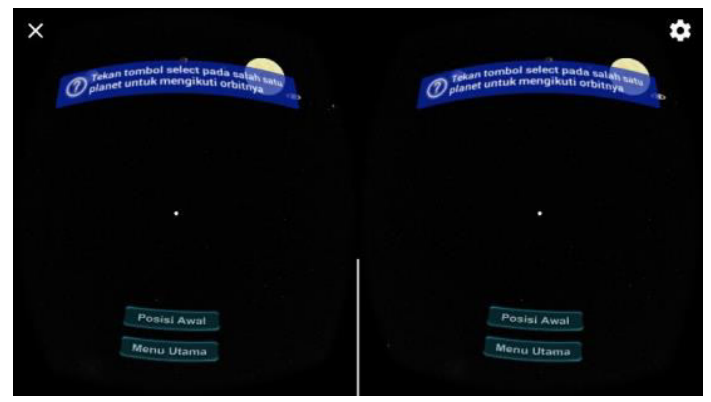

Gambar 9. Hasil Pengembangan Antarmuka Simulasi Tata Surya

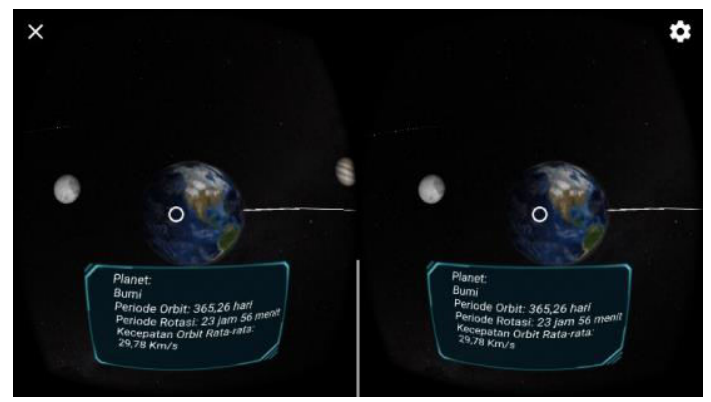

Gambar 10. Hasil Pengembangan

Antarmuka Deskripsi Planet 
Antarmuka pada Gambar 9 dan 10 akan ditampilkan apabila pengguna memilih Menu Simulasi Tata Surya pada menu utama. Di bagian tengah layar akan terdapat penunjuk atau pointer yang berfungsi sebagai penunjuk bagian mana yang akan dipilih oleh pengguna. Tombol "menu utama" berfungsi untuk kembali ke menu utama dan tombol reset posisi untuk mengembalikan posisi pengguna ke lokasi awal dimulainya fitur simulasi tata surya ini.

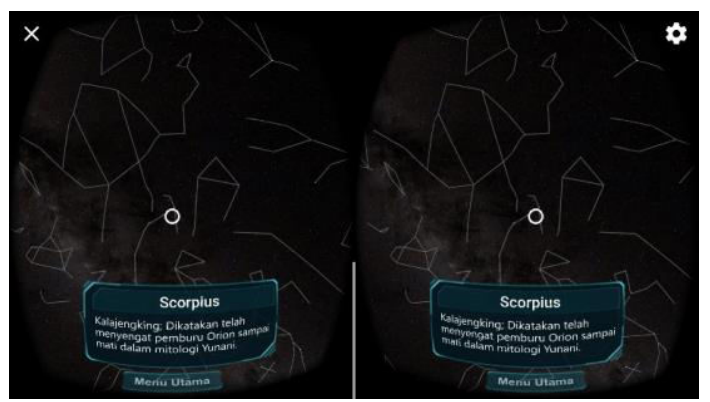

Gambar 11. Hasil Pengembangan Antarmuka Rasi Bintang

Antarmuka rasi bintang ini akan ditampilkan apabila pengguna memilih Menu Rasi Bintang pada menu utama. Pengguna dapat mengeksplorasi sendiri rasi-rasi bintang yang ada. Apabila pengguna mengarahkan pointernya kesalah satu rasi bintang, maka akan muncul deskripsi dari rasi bintang tersebut. Di bagian tengah layar akan terdapat penunjuk atau pointer yang berfungsi sebagai penunjuk bagian mana yang akan dipilih oleh pengguna. Tombol "menu utama" berfungsi untuk kembali ke menu utama.

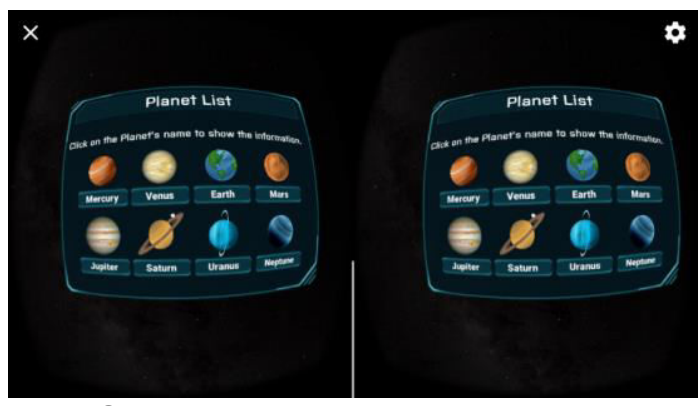

Gambar 12. Hasil Pengembangan Antarmuka Tur Planet

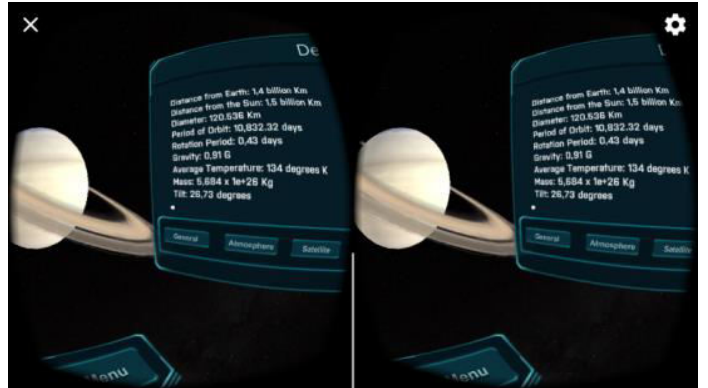

Gambar 13. Hasil Pengembangan Antarmuka Detail Planet

Antarmuka pada Gambar 12 dan 13 akan ditampilkan apabila pengguna memilih Menu Tur Planet pada menu utama. Selanjutnya akan tampil antarmuka yang menampilkan daftar planet yang dapat dikunjungi oleh pengguna. Pengguna perlu mengarahkan pointer ke salah satu nama planet setelah beberapa saat akan muncul planet yang dipilih beserta informasinya. Pengguna dapat kembali ke daftar atau melihat planet lain dengan cara memilih salah satu nama planet yang tersedia. Tombol "menu utama" berfungsi untuk kembali ke menu utama.

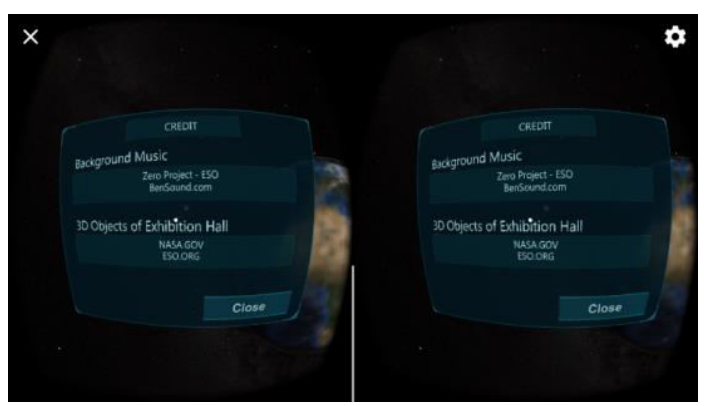

Gambar 14. Hasil Pengembangan Antarmuka Credit

Antarmuka Credit ini akan ditampilkan apabila pengguna memilih Menu Credit pada menu utama. Tampilan Kredit Aplikasi ini nantinya akan ditampilkan secara virtual reality di mana layar akan terbagi menjadi dua sisi yaitu sisi kanan dan sisi kiri. Di bagian tengah layar akan terdapat penunjuk atau pointer yang berfungsi sebagai penunjuk bagian mana yang akan dipilih oleh pengguna. Tombol tutup akan menutup menu antarmuka tentang pengembang dan menampilkan antarmuka Menu Utama.

\section{Hasil Tahap Implementation}

Tahap implementasi adalah tahap saat aplikasi telah siap untuk diperkenalkan dan dilakukan pengujian kelayakan. Pada tahap ini dilakukan implementasi aplikasi Planetarium berbasis Virtual Reality pada smartphone masyarakat. 
Sebelum dapat digunakan, pengguna harus memasang aplikasi Planetarium berbasis Virtual Reality pada smartphone. Untuk dapat diimplementasikan, maka perangkat keras baik itu perangkat keras smartphone dan perangkat keras virtual reality viewer harus memenuhi beberapa spesifikasi seperti di bawah ini.

\section{a. Perangkat Keras Smartphone}

Berikut merupakan spesifikasi minimum perangkat keras smartphone yang dapat digunakan untuk menjalankan aplikasi Planetarium berbasis Virtual Reality.

1) Prosesor: Quad-Core $1,5 \mathrm{Ghz}$

2) Layar: 4,5 inchi dengan resolusi 1280x720 pixel

3) Memory: Internal $1 \mathrm{~GB}, \mathrm{RAM} 2 \mathrm{~GB}$

4) Sensor: Gyroscope dan Accelerometer

5) Konektivitas: Bluetooth

6) Sistem Operasi: Android 4.1 Jelly Bean

b. Perangkat Keras Virtual Reality Viewer

Untuk dapat menggunakan aplikasi Planetarium berbasis Virtual Reality ini dengan maksimal, dibutuhkan perangkat Virtual Reality Viewer atau kacamata Virtual Reality beserta remote controller yang terhubung ke perangkat smartphone dengan menggunakan bluetooth.

\section{Hasil Tahap Evaluation}

Evaluasi yang peneliti lakukan pada pengembangan aplikasi Planetarium berbasis Virtual Reality ini adalah sebanyak 2 jenis. Yang pertama adalah pengujian untuk mengetahui respon pengguna setelah menggunakan aplikasi ini dan yang kedua adalah uji usability. Dari pengujian yang dilakukan terhadap 35 pengguna didapatkan rata-rata persentase respon dalam hal ini kepuasan pengguna yaitu sebesar $93 \%$. Berdasarkan hasil tersebut maka aplikasi Planetarium Berbasis Virtual Reality masuk dalam kriteria sangat baik dimana pengguna dalam hal ini masyarakat umum dapat menggunakan aplikasi dengan mudah dan sangat tertarik untuk mencoba menggunakan aplikasi ini.

Evaluasi yang selanjutnya adalah evaluasi untuk mengetahui seberapa jauh kebutuhan non-fungsional dapat terpenuhi. Evaluasi terkait kebutuhan non-fungsional ini peneliti lakukan dengan menggunakan metode UEQ atau User Experience Quistionneir. Responden pada pengujian usability ini berjumlah 10 orang yang dibagi menjadi dua kategori yaitu kategori pakar teknologi dan kategori non pakar. Dari hasil analisis yang dilakukan dengan mengubah 26 item penilaian pada angket UEQ menjadi 6 skala yaitu daya tarik, kejelasan, efisiensi, ketepatan stimulasi, dan kebaruan, aplikasi Planetarium berbasis Virtual Reality mencapai hasil 2,167 untuk skala daya tarik, dan termasuk kedalam kategori sangat baik. Skala kejelasan 1,575 dengan predikat baik. Efisiensi mencapai nilai 2, ketepatan mencapai nilai 1,9 ; stimulasi mencapai nilai 2,25 ; dan skala yang terakhir yakni skala kebaruan yang mencapai nilai 1,925 atau dengan predikat sangat baik. Hasil uji usability aplikasi Planetarium berbasis Virtual Reality dengan metode UEQ menunjukkan bahwa aplikasi memiliki tingkat kejelasan, efisiensi, ketepatan, stimulasi, dan kebaruan yang baik sehingga dapat digunakan oleh masyarakat umum.

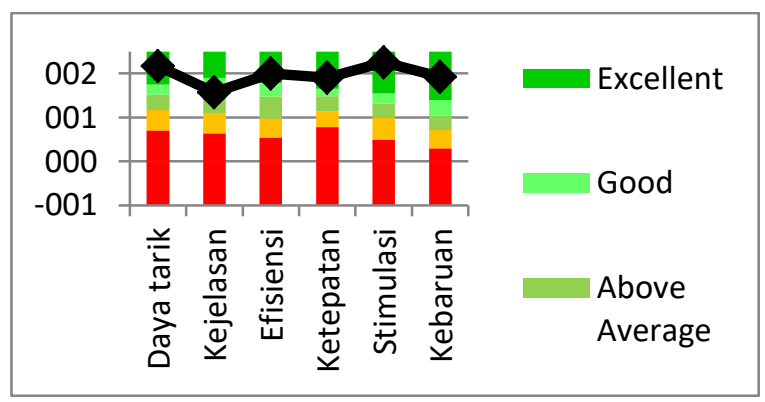

Gambar 15. Grafik Hasil Akhir Uji Usability dengan Metode UEQ

\section{SIMPULAN}

Berdasarkan hasil analisis, desain, pengembangan, implementasi dan pengujian pada penelitian pengembangan aplikasi Planetarium Berbasis Virtual Reality dapat ditarik kesimpulan sebagai berikut: (1) Pengembangan aplikasi Planetarium Berbasis Virtual Reality menggunakan metode Research and Development (R\&D) dengan model pengembangan Analisys, Design, Development, Implementation, Evaluation (ADDIE). Aplikasi pendukung yang digunakan dalam pengembangannya yaitu Unity, GoogleVR SDK for Unity, Blender 3D, GIMP, dan Audacity. Aplikasi Planetarium Berbasis Virtual Reality dapat dipasang pada smartphone Android dengan versi minimum Android 4.1 (Jelly Bean). Aplikasi ini memiliki 4 fitur utama yaitu ruang pameran, simulasi tata surya, rasi bintang, dan tur Planet. (2) Implementasi Aplikasi Planetarium Berbasis Virtual Reality mendapatkan respon baik dari masyarakat umum, mereka sangat tertarik dan antusias untuk mencoba aplikasi dan belajar mengenai sistem tata surya, rasi bintang, planet-planet di sistem tata surya dan alat-alat yang digunakan 
dalam bidang ilmu astronomi. Dari hasil uji respon di lapangan terhadap 35 masyarakat umum yang terbagi kedalam 5 segmen yakni siswa SD, siswa SMP, siswa SMA, mahasiswa, dan masyarakat umum lainnya sebagai responden di dapatkan hasil sebesar $93 \%$ yang artinya aplikasi masuk kategori sangat baik.

\section{SARAN}

Berdasarkan pengamatan peneliti di lapangan, terdapat beberapa hal yang dapat dijadikan bahan pertimbangan untuk pengembangan berikutnya antara lain: (1) Memperhatikan teknik optimasi sehingga dapat menghasilkan suatu aplikasi Virtual Reality yang jelas dan lebih nyata namun tidak mengurangi kecepatan aplikasi. (2) Fitur rasi bintang yang lebih dinamis sehingga pengamatan rasi bintang dapat mengikuti waktu dan lokasi pengamat. Pada fitur ruang pameran diharapkan pada pengembangan selanjutnya dapat menambah obyek-obyek lainnya. (3) Meminimalkan waktu Loading. (4) Perlu dilakukan analisis lebih mendalam terkait UX (user experience) agar pengembang memahami kebutuhan-kebutuhan pada aplikasi terkait desain maupun fitur yang bisa dikembangkan.

\section{DAFTAR PUSTAKA}

[1] M. R. Chartrand, A Fifty Year Annyversary of a Two Thousand Year Dream (The History of the Planetarium), New York: IPC, 1973.

[2] B. D. Sihite, "Pembuatan Aplikasi 3D Viewer Mobile dengan Menggunakan Teknologi Virtual Reality," JURNAL TEKNIK POMITS, Vols. Vol. 2, No. 2, pp. 397-398, 2013.

[3] KZero, "Number of virtual reality users worldwide 2014-2018," 2014. [Online]. Available: https://www.statista.com/statistics/426469/activevirtual-reality-users-worldwide/. [Accessed 2017].

[4] T. Budiarto, "Planetarium Tawangmangu," Surakarta, 2008.

[5] A. D. Mauro, "Virtual Reality Based Rehabilitation And Game Technology," eHealth \& Biomedical Applications, pp. 48-52, 2009.
[6] A. Developer, "What is android," 2011.

[7] N. Yulianto, Pembuatan Game 3 Dimensi Lost In The Jungle Dengan Menggunakan Unity 3D Game Engine. Naskah Publikasi-Teknik Informatika. Sekolah Tinggi Manajemen Informatika dan Komputer AMIKOM, Yogyakarta, 2012.

[8] Google, "Google VR SDK for Unity," 9 Februari 2017. [Online]. Available:

https://developers.google.com/vr/unity/.

[9] Blender Foundation, "About Blender," 2015. [Online]. Available:

https://www.blender.org/about/. [Accessed 17 Februari 2017].

[10] E. Forest, "The ADDIE Model: Instructional Design," 2014. [Online]. Available:

http://educationaltechnology.net/the-addiemodel-instructional-design/. [Accessed 163 2017].

[11] Sugiyono, Metode Penelitian Pendidikan (Pendekatan Kuantitatif, Kualitatif dan R\&D), Bandung: Alfabeta, 2012.

[12] G. Muruganantham, "Developing of E-content package by using ADDIE Model," International Journal of Applied Research, pp. 52-54, 2015.

[13] R. S. W. Sri Dharwiyanti, "Pengantar Unified Modeling Language (UML)," 2003. [Online]. Available: rosni-gj.staff.gunadarma.ac.id. [Accessed 2017].

[14] D. Ford, "List of the Constellations," 2017. [Online]. Available: https://in-thesky.org/data/constellations_list.php. 
ISSN 2089-8673 (Print) | ISSN 2548-4265 (Online) Volume 7, Nomor 2, Juli 2018

Jurnal Nasional Pendidikan Teknik Informatika | 219 